\title{
Soil Disturbance Impact on Crop Ergothioneine Content Connects Soil and Human Health
}

\author{
Robert B. Beelman ${ }^{1, *}$, John P. Richie, Jr. ${ }^{2}$, Allen T. Phillips ${ }^{3}$, Michael D. Kalaras ${ }^{1}$, Dongxiao Sun ${ }^{4}$ and \\ Sjoerd W. Duiker 5
}

1 Department of Food Science, College of Agricultural Sciences, Penn State University, 202 Rodney A. Erickson Food Science Building, University Park, State College, PA 16802, USA; mdk219@psu.edu

2 Department of Public Health Sciences, College of Medicine, Penn State University, 500 University Dr., Hershey, PA 17033, USA; jrichie@pennstatehealth.psu.edu

3 Department of Biochemistry and Molecular Biology, Eberly College of Science, Penn State University, 203A South Frear Building, University Park, State College, PA 16802, USA; atp@psu.edu

4 Department of Pharmacology, Mass Spectrometry Core Facilities, College of Medicine, Penn State University, 500 University Dr., Hershey, PA 17033, USA; dsun@pennstatehealth.psu.edu

5 Department of Plant Science, College of Agricultural Sciences, Penn State University, 408 ASI Building, University Park, State College, PA 16802, USA; sduiker@psu.edu

* Correspondence: rbb6@psu.edu

check for updates

Citation: Beelman, R.B.; Richie, J.P., Jr.; Phillips, A.T.; Kalaras, M.D.; Sun, D.; Duiker, S.W. Soil Disturbance Impact on Crop Ergothioneine Content Connects Soil and Human Health. Agronomy 2021, 11, 2278. https://doi.org/10.3390/agronomy 11112278

Academic Editor: Sara Di Lonardo

Received: 23 September 2021 Accepted: 8 November 2021

Published: 11 November 2021 Corrected: 31 July 2021

Publisher's Note: MDPI stays neutral with regard to jurisdictional claims in published maps and institutional affiliations.

Copyright: (c) 2021 by the authors. Licensee MDPI, Basel, Switzerland. This article is an open access article distributed under the terms and conditions of the Creative Commons Attribution (CC BY) license (https:/ / creativecommons.org/licenses/by/ $4.0 /)$.

\begin{abstract}
Ergothioneine (ERGO) is a potent antioxidant and anti-inflammatory amino acid that is produced in nature mainly by non-yeast fungi, cyanobacteria, and mycobacteria. Mounting evidence suggests that ERGO can be considered a longevity vitamin that can mitigate chronic diseases of aging and thereby increase life expectancy. Humans must obtain ERGO from their diet, and it is therefore important to know which foods contain it. Although ERGO is not produced by plants it is found in plant products such as grain, apparently because detrital or symbiotic soil fungi pass on ERGO to plants through their roots. Besides differences between plant species in their ability to accumulate ERGO, how they are managed might also affect its concentration. Soil tillage has been shown to reduce soil fungal biomass, and therefore ERGO contents in maize, soybeans, and oats grown in soil managed with annual moldboard plowing (most intensive), chisel/disking (less intensive), or no-tillage (least intensive) in crop rotation were compared. ERGO concentrations declined in all three crops as tillage intensity increased, with reductions from no till to moldboard plow of approximately $30 \%$ in all three crops. Because crop yield was also negatively impacted by intensive tillage, ERGO yield per hectare was reduced even more due to increasing tillage intensity. This study is one of the first to show that soil health improving practices that minimize soil disturbance can directly enhance a key dietary factor associated with long-term human health.
\end{abstract}

Keywords: ergothioneine; tillage; soil disturbance; soil health; regenerative agriculture

\section{Introduction}

A recent study hypothesized that an important link between soil health and human health is the potent dietary antioxidant amino acid, ergothioneine (ERGO) [1]. Ames previously suggested that ERGO is a "longevity vitamin" and lack of it in the diet can result in a greater incidence of chronic diseases of aging and reduced life expectancy, and because it is not produced by the human body, it must be obtained through the diet [2] Unfortunately, the American diet has been shown to be quite low in ERGO compared to four European countries, and this lack was associated with a higher incidence of chronic diseases of aging and reduced life expectancy [1]. ERGO is produced in nature primarily by fungi and some bacteria [3-6]. Cultivated mushrooms have been shown to be, by far, the leading dietary source of ERGO. However, it is also detected in small quantities in plants, even though plants are not known to produce ERGO themselves. It appears, therefore, that soil microorganisms such as mycorrhizae and saprobic fungi pass ERGO on to plants 
through their roots, and it then becomes widely distributed in the food chain. Research has demonstrated that tillage of agricultural soils can disrupt and diminish saprobic and mycorrhizal fungi populations and thereby compromise soil health [7-10]. This led us to speculate that minimal or no tillage could help to maintain robust levels of soil-borne fungi and thereby result in crops with higher ERGO levels than if grown with aggressive tillage [1].

Scientists define soil health (sometimes called soil quality) as "the capacity of a living soil to function, within natural or managed ecosystem boundaries, to sustain plant and animal productivity, maintain or enhance water and air quality, and promote plant and animal health" [11]. The link between soil health and human health, however, has proven elusive [12]. Sometimes soil health is limited to the ability of soil to supply essential nutrients and water to plants, or the absence of soil pollutants $[13,14]$. However, this ignores the biological aspect of soil health [11]. Soil health is determined by an active soil food web, its foundation being photosynthetic autotrophs that feed a large diversity of heterotrophs ranging from submicroscopic organisms to large burrowing animals that live in soil. Soil health is determined by the entire sequence, from living organisms, to dead organisms, all the way through a cascade of trophic levels to highly stable organic humified compounds that are physically protected inside soil aggregates. Soil organic matter content, which encompasses all living and dead organisms and humus, is therefore one of the most important indicators of soil health [15]. The living portion of soil, however, is still very poorly understood, because most species are submicroscopic and techniques to identify them are still in development [16]. A tablespoon (about $15 \mathrm{~g}$ ) of soil typically contains more than 1 billion bacterial cells, representing thousands to millions of individual species, most of which are not identified at the species level [17]. Our understanding of microbial diversity has improved tremendously in the last 30 years, but much still remains to be discovered [16]. Better characterization of the diversity of submicroscopic soil organisms and understanding of their respective roles will be essential to the development of management practices that result in more healthy soil.

Despite the need for a better understanding of soil microbes, broad categories are already identified and their importance for soil health recognized. The kingdom of fungi has been found to be especially important to soil health. Saprophytic fungi are crucial to the decomposition of highly lignified plant matter, liberating nutrients for other microbes and higher life forms [18]. Saprobic soil fungi that decompose dead plant and animal remains stimulate macroaggregate formation-critical for erosion resistance, soil aeration, water infiltration, and percolation [19]. Mycorrhizal fungi live in symbiotic relationship with plant roots common in more than $80 \%$ of plant species [20]. Arbuscular mycorrhizae are most common, which penetrate plant roots and form tree-like structures inside root cortical cells where the exchange of carbohydrates, nutrients, and water between plant and fungus takes place [21]. Other plants (mostly perennial tree species) have associations with ectomycorrhizae, the hyphae of which only penetrate the intercellular spaces between root cortical cells where energy, nutrient, and water exchange take place [22]. Mycorrhizae are important for soil health for several reasons: (1) they favor soil aggregation because their hypha form nets that stabilize macroaggregates, while they also produce glomalin, a hydrophobic glycoprotein that acts as a glue between soil particles and (2) they extend the reach of plant roots and increase access to immobile plant nutrients such as phosphorus and potassium, increase water uptake, and also produce exudates and enzymes that help solubilize nutrients from soil minerals and organic matter [23].

Recently, there has been a movement to make changes to conventional agricultural practices that can lead to improvements in soil health. Regenerative, restorative, and conservation agriculture have all been employed to describe this movement. All of these employ the combination of three principles: (1) no or limited soil disturbance, (2) permanent organic cover of the soil, and (3) diversity in crop rotations and/or associations [24]. Compared with conventional crop production, conservation agriculture leads to reduced soil erosion $[25,26]$ greater infiltration $[27,28]$, more soil organic carbon $[29,30]$, soil structure 
development [31], more earthworms [32,33], improved biological nitrogen fixation [34], fungal hyphae growth [10], and arbuscular mycorrhizae colonization [9,35]. More healthy food from conservation agriculture due to its improvement in soil health, however, remains to be confirmed. To address this gap in knowledge, our objective was to determine the specific impact of tillage on the content of ERGO in grain crops utilizing an existing 40+ year tillage study. We hypothesized that increased tillage would lead to lower levels of ERGO when compared to crops grown using minimal or no-till methods.

\section{Materials and Methods}

\subsection{Cultivation of Grain Crops}

Grain was obtained from the continuous, long-term tillage trial at the Russell E. Larson Agricultural Research Center at Rock Springs as described previously [36]. The tillage study was started in 1978 in a randomized complete block design with three tillage treatments: moldboard plowing/disking/harrowing (MB), chisel plowing/disking/harrowing (CD), and no-till (NT), replicated four times. Plots were $225 \mathrm{~m}$ long by $14 \mathrm{~m}$ wide (with exception of no-till in the 4th replicate, which was $188 \mathrm{~m}$ long). The field was undulating, with the first replicate being at the lowest position and the fourth replicate at a higher position in the landscape. The first replicate was subject to repeated extended flooding events and standing water in the last 10 years and was therefore excluded from the analysis in this paper. The soils of replications $2-4$ that are the subject of this study are primarily classified as Hagerstown silt loam (mixed, semiactive, mesic Hapludalf in the USDA Taxonomy). These are well-drained limestone-derived valley soils common in the Ridge and Valley ecoregion that stretches from western Virginia to northeastern Pennsylvania.

After 25 years of continuous maize (Zea mays, L.) with occasional exceptions, the study was converted in 2004 to a more diverse maize-soybean (Glycine max L. Merr)-wheat (Triticum aestivum L.) rotation followed by a leguminous cover crop. Maize and soybeans were usually planted in May, while wheat was planted immediately after soybean harvest in the fall (typically October). After wheat harvest, a hairy vetch (Vicia villosa, Roth)/oat (Avena sativa L.) cover crop was planted in the second half of August. In some years it was not possible to plant wheat after soybeans in the fall due to late soybean harvest or extremely wet conditions in the fall, so oats were planted in April instead. Therefore, oats were grown in 2020 instead of wheat.

Tillage for $\mathrm{MB}$ and $\mathrm{CD}$ was done annually before main crop or cover crop establishment. This was in April/May for summer crops maize, soybean, and oats, October for wheat, and August for the cover crop. In the case of MB, primary tillage was done with an International 710 Automatic (with six general purpose bottoms and trash boards for better residue coverage). One side of the tractor drives in the front furrow, and the depth of tillage was $30-35 \mathrm{~cm}$. The moldboard plow inverts the soil and leaves virtually no crop residue cover after planting. In the case of CD, a John Deere 714 chisel plow was used. This model has one row of spherical disks up front to cut crop residue and three rows of $7.6 \mathrm{~cm}$ wide twisted points, totaling 11 chisel points. The depth of tillage was $20-25 \mathrm{~cm}$. Chisel plowing is a much less intensive tillage operation than moldboard plowing, does not completely invert the topsoil, and leaves more crop residue cover after planting. Secondary tillage was the same for $\mathrm{CD}$ and MB and included disking with a Pittsburgh MT10 tandem disk. This disk has $48 \mathrm{~cm}$ diameter spherical notched disks on the front and $43 \mathrm{~cm}$ diameter spherical smooth disks on the rear. The depth of disk harrowing was approximately $10 \mathrm{~cm}$ deep. Disking was followed by final seedbed preparation with a Brillion cultimulcher spring-tooth harrow. This harrow has one row of crowsfoot cultipacker wheels followed by two rows of spring-tooth harrow tines, followed by one row of solid cultipacker wheels to firm up the soil. The depth of the spring-tooth tillage was approximately $8-10 \mathrm{~cm}$. All treatments were planted with a no-till planter or drill after tillage was completed in the respective plots. Maize was planted with a 6-row (4.56 m wide) John Deere no-till planter (JD 1780 from 2001-2014, and JD 1755 from 2015-2019) with $76 \mathrm{~cm}$ row spacing. Soybeans, wheat, oats, and cover crops were planted with a $3 \mathrm{~m}$ wide Great Plains no- 
till drill with $19 \mathrm{~cm}$ row spacing. Typical plant populations were $79,000 \mathrm{ha}^{-1}$ for maize, $430,000 \mathrm{ha}^{-1}$ for soybeans, and $3.5 \mathrm{million} \mathrm{ha}^{-1}$ for wheat and oats. Cover crop seeding rate was $36 \mathrm{~kg} \mathrm{ha}^{-1}$ oats and $28 \mathrm{~kg} \mathrm{ha}^{-1}$ hairy vetch. Soybeans and hairy vetch were inoculated with the proper rhizobial bacteria for biological nitrogen fixation. Crops were fertilized with chemical fertilizer and no animal manure or compost was used. The soil in the experiment was tested regularly and lime, phosphorus, and potassium were applied according to recommendations by Penn State's Agricultural Analytical Laboratory. Nitrogen was applied according to yield goal, which typically meant $168 \mathrm{~kg} \mathrm{ha}^{-1}$ total N was applied for maize (split between at planting and side-dress application) and $70 \mathrm{~kg} \mathrm{ha}^{-1} \mathrm{~N}$ for wheat and oats (topdressed in spring), while no nitrogen was applied to soybeans, since it fixes atmospheric nitrogen. Herbicides were used for weed control. The same herbicides were used in all tillage treatments. This involved annual glyphosate application before crop establishment to kill all living vegetation, and another post-emergence glyphosate application in soybeans. In the case of maize, a residual herbicide program was used. No in-crop herbicide application was used for wheat or oats. Glyphosate has been used in these tillage study plots for at least 20 years annually for burn-down as well as during crop growth when glyphosate-resistant crops were utilized, i.e., soybeans.

Crop yields were determined by combine harvesting the center $4.56 \mathrm{~m}$ of each plot and weighing the grain in a weighing wagon. Random samples were taken from each load to determine moisture content. Grain yields are reported at standard moisture contents. For the present study, random samples of maize (2018), soybeans (2019), and oats (2020) were collected for ERGO analysis. Random samples were obtained while the fields were harvested and stored. Prior to ERGO analysis, samples were hot air dried at $55^{\circ} \mathrm{C}$ for $10 \mathrm{~h}$ to account for any moisture gain during storage. The dried samples were then ground into a fine powder using a Vitamix Blender equipped with a 32-ounce dry grain container. In the case of maize (2018), the samples were collected as an exploratory experiment to see if differences in tillage led to difference in ERGO. For this reason, ERGO results are from a pooled sample analysis without controlled reps for each tillage type. In subsequent years replicates were available. Thus, statistical analysis was not performed for ERGO in maize (2018).

\subsection{Analysis of ERGO Content in Crop Samples \\ 2.2.1. Chemicals and Materials}

L-(+)-ergothioneine standard was purchased from Toronto Research Chemicals (Toronto, ON, CA), and L-(+)-ergothioneine-d9 (ERGO-d9) was purchased from Santa Cruz Biotechnology (Dallas, TX, USA) as internal standard. Formic acid was purchased from ACROS (Fair Lawn, NJ, USA). Optima LC-MS grade water, acetonitrile, methanol, and other chemicals were purchased from Fisher Scientific (Fair Lawn, NJ, USA).

\subsubsection{Sample Preparation Procedure}

ERGO and ERGO-d9 stock solutions $(1 \mathrm{mg} / \mathrm{mL})$ were prepared in methanol. The standard working solutions were prepared by series dilution of the standard stock solution in methanol/water (50/50), resulting in concentrations from 50 to $10,000 \mathrm{ng} / \mathrm{mL}$. ERGO-d 9 working solution was prepared by dilution of its stock solution using methanol/water $(50 / 50)$ to make the concentration at $500 \mathrm{ng} / \mathrm{mL}$. ERGO standard curve was prepared by spiking $5 \mu \mathrm{L}$ of standard working solution and $2.5 \mu \mathrm{L}$ of internal standard working solution into $42.5 \mu \mathrm{L}$ of $50 \%$ methanol to make the standard concentrations from 5 to $1000 \mathrm{ng} / \mathrm{mL}$ while the internal standard concentration was kept at $25 \mathrm{ng} / \mathrm{mL}$. The standard curves were constructed by plotting the ratio of the peak area of ERGO to the peak area of ERGO-d9 versus ERGO concentration. The stock solutions and working solutions were kept at $-20^{\circ} \mathrm{C}$ before use.

The grain samples were ground into powder before being processed. After weighing the grain powders (around $50 \mathrm{mg}$ ), $10 \mu \mathrm{L}$ of internal standard working solution was spiked in, and $990 \mu \mathrm{L}$ of methanol was used to extract ERGO from the grain powder. The mixture 
was vortexed, and centrifuged at $4{ }^{\circ} \mathrm{C}, 8765 \times g$ for $10 \mathrm{~min}$, and the supernatant was diluted by an equal volume of water before being loaded onto a UPLC-MS/MS system for analysis.

\subsubsection{UPLC-MS/MS Analysis}

ERGO was analyzed using a Sciex 4000 Q Trap mass spectrometer coupled with a Waters ACQUITY UPLC separation system. A 1.7 $\mu \mathrm{m}$ ACQUITY UPLC BEH C18 analytical column $(2.1 \times 100 \mathrm{~mm}$, Waters, Ireland $)$ was used with the following mobile phase: mobile phase A consisted of $0.1 \%$ formic acid in water and mobile phase B consisted of acetonitrile. The gradient elution was conducted using a flow rate of $0.3 \mathrm{~mL} / \mathrm{min}$ with the following conditions: initiate at 1\% mobile phase B, linear gradient to $80 \%$ mobile phase B in $2.5 \mathrm{~min}$, and further gradient to $100 \%$ mobile phase B in $1 \mathrm{~min}$. Mobile phase B was continued at $100 \%$ for another $1 \mathrm{~min}$ to flush the column before returning to initial conditions to equilibrate the column. The autosampler was kept at $4^{\circ} \mathrm{C}$, and the column temperature was maintained at $30^{\circ} \mathrm{C}$.

The Sciex 4000 QTrap mass spectrometer was equipped with an electrospray ionization probe operated in positive mode. The decluster potential was $52 \mathrm{~V}$; the entrance potential was $10 \mathrm{~V}$; the collision energy was $29 \mathrm{~V}$ for ERGO and $25 \mathrm{~V}$ for ERGO-d9; and the collision cell exit potential was $9.9 \mathrm{~V}$, while the curtain gas was $30 \mathrm{~L} / \mathrm{h}$ and the collision gas was $10 \mathrm{~L} / \mathrm{h}$. The ionSpray voltage was $5500 \mathrm{~V}$, the temperature was $500{ }^{\circ} \mathrm{C}$, the ion source gas 1 was $60 \mathrm{~L} / \mathrm{h}$, and the ion source gas 2 was $20 \mathrm{~L} / \mathrm{h}$. The multiple reaction monitoring mode was used to analyze and quantify ERGO and ERGO-d9, with transitions of $m / z$ at $230.3>127.3$ for ERGO and $m / z$ at $239.3>127.3$ for ERGO-d9. All peaks were integrated and quantified by Sciex MultiQuant 2.1 software (Sciex, Framingham, MA, USA).

\subsection{Statistical Analysis}

Data were entered in Microsoft Excel and subsequently imported into R studio. Prior to statistical analysis, the data were tested for normality. Crop yield, ERGO concentration, and ERGO yield were analyzed in the statistical package R Studio (R version 4.0.3) (Boston, MA, USA). A least squares analysis of variance (ANOVA) was performed and, if the F-test was significant at $p<0.05$, then the separation of means was calculated using the least significant difference test at $p<0.05$.

\section{Results}

The effect of soil tillage on the ERGO content of maize, soybeans, and oats is presented in Figure 1. A trend was observed where ERGO concentrations generally declined as tillage intensity increased from NT to CD to MB. ERGO content was decreased from NT to MB by $31 \%, 33 \%$, and $28 \%$ for maize, soybeans, and oats, respectively. The data from maize grown in 2018 (Figure 1a) were derived from pooled samples of all four replications from each tillage treatment. Hence, no statistical comparison was possible, but a clear trend of declining ERGO with more aggressive tillage was evident. The same trend observed with maize was observed with oats (Figure 1c). A significant reduction in the ERGO content of oats only occurred when comparing NT with the most aggressive tillage method (MB), with CD not being significantly different from either one of those, showing it is intermediate in its effect on ERGO. In soybeans, the trend was similar (Figure 1b); however, the difference in ERGO between CD and MB was significant, while NT was slightly lower than CD but not significant. The overall ERGO levels of maize and soybeans were similar to each other while ERGO levels in oats were much higher. This was not surprising since oats have previously been reported to be one of the best dietary sources of ERGO $[1,37,38]$.

The effect of tillage on crop yields is illustrated in Figure 2. A trend is evident in which increasing tillage generally leads to a decrease in yield. NT resulted in the highest maize and soybean yields, followed by $\mathrm{CD}$ and then $\mathrm{MB}$, with only the difference between $\mathrm{MB}$ and NT being significant. Oat yields were similar in CD and NT and lower in MB with only the difference between $\mathrm{MB}$ and $\mathrm{CD}$ being significant. In all three crops, the use of 
MB resulted in the lowest yields. Aggressive tillage using MB compared to NT decreased yields by $6.5 \%, 26 \%$, and $3.7 \%$ in maize, soybeans, and oats, respectively.

Another way to assess the effects of tillage on ERGO is by expressing ERGO production per hectare (Figure 3). For this estimation, the ERGO data was multiplied by yield per hectare and multiplied by 1000 to give the approximate amount of ERGO in grams per hectare. For oats, a yield correction factor of 0.75 was used to account for the ERGO being measured in dehulled oats as opposed to whole oats, which accounts for approximately $75 \%$ of the whole grain. When expressed in this fashion, the ERGO production in all crops was greater in NT than in MB. In soybean and oats, production was similar for NT and CD. In maize, each tillage treatment for ERGO per hectare was significantly different from one another. Elimination of tillage had a positive effect on both crop yield and ERGO content in the crops, which suggests that there was no dilution effect due to yield responsible for the higher ERGO in NT crops.
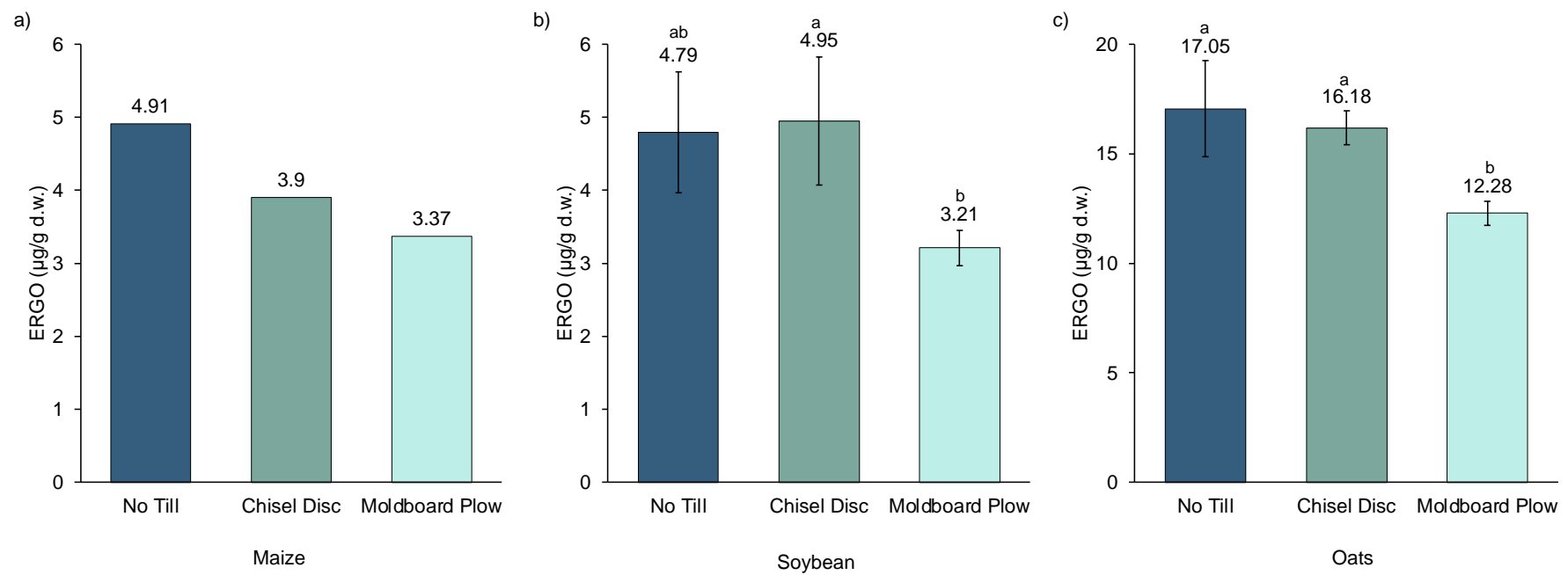

Figure 1. ERGO content of crops (a) maize (2018), (b) soybean (2019), and (c) oats (2020) grown using different tillage methods; different letters above the bars indicate significant difference $(p>0.05)$ within each crop type, error bars represent the standard deviation of each tillage type.
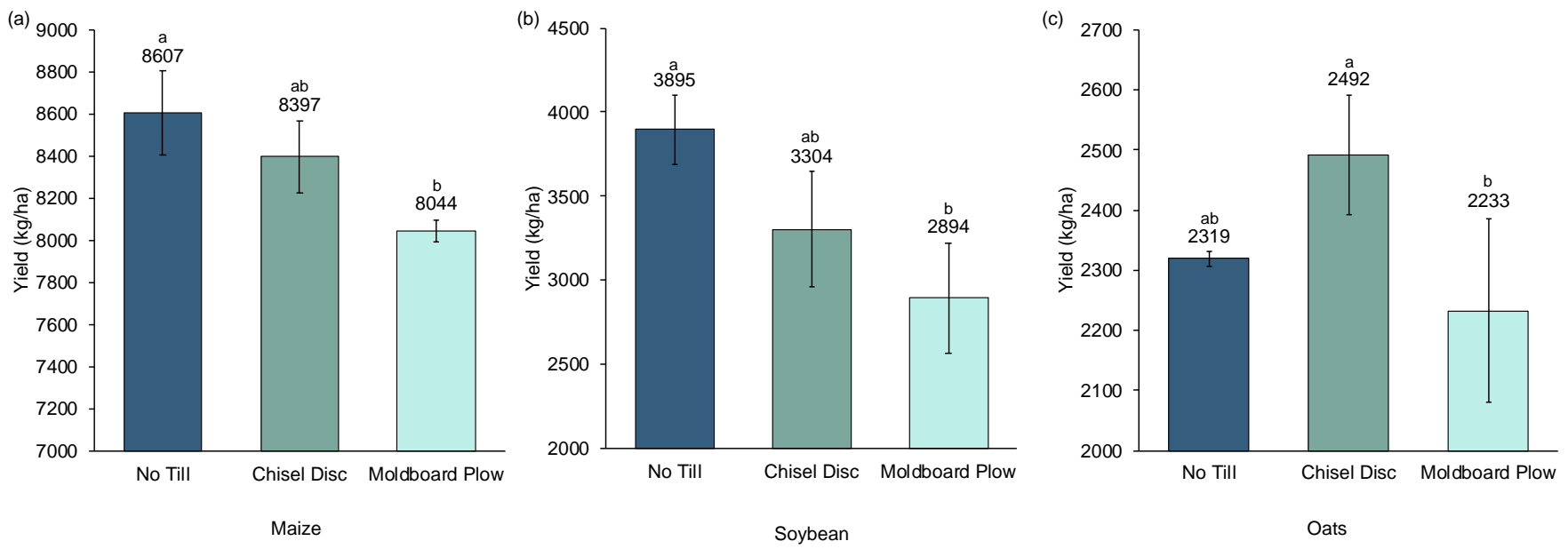

Figure 2. Yield of crops (a) maize (2018), (b) soybean (2019), and (c) oats (2020) grown using different tillage methods; different letters above the bars indicate significant difference $(p>0.05)$ within each crop type, error bars represent the standard deviation of each tillage type. 

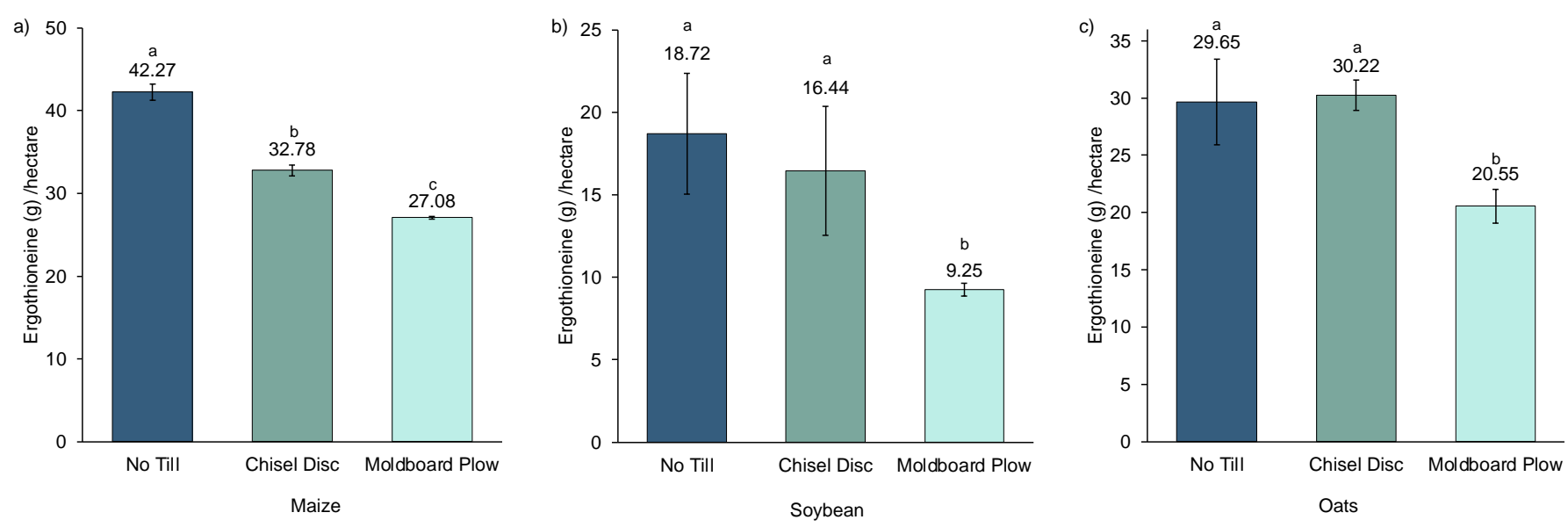

Figure 3. Ergothioneine production per hectare of crops (a) maize (2018), (b) soybean (2019), and (c) oats (2020) grown using different tillage methods; different letters above the bars indicate significant difference $(p>0.05)$ within each crop type, error bars represent the standard deviation of each tillage type.

\section{Discussion}

Aggressive tillage of the soil is still a common practice in conventional agriculture in many countries. According to the 2017 U.S. Agricultural Census, intensive till was used on 32.4 million ha $(28 \%)$, reduced till on 39.6 million ha $(35 \%)$, and NT on 42.3 million ha (37\%) [39]. We speculated that aggressive tillage of the soil might lead to a reduced amount of a putative longevity vitamin, ERGO, in the food supply [1]. Our hypothesis was based on the possibility that tillage of the soil disrupts mycorrhizal and saprobic fungal networks in the soil as previously reported [7,10,35]. Mycorrhizal fungi live in symbiotic association with the roots of plants and can presumably pass ERGO to plants, but the specific mechanism remains unknown. Saprobic fungi and actinobacteria that do not live in symbiosis with plant roots may produce ERGO as well [40]. If they release ERGO into the soil, it might be taken up by plant roots as was reported previously [41]. Since only the mycorrhizal fungi are known to have a symbiotic relationship with roots of plants, however, they are likely the primary source of ERGO in the food supply. The results presented in Figure 1 showing the negative effects of tillage on the ERGO content of food crops appear to support this hypothesis. However, it was demonstrated that the degree of tillage was also important. Significant negative effects were observed when NT was compared with the most aggressive MB tillage. The use of the less aggressive CD had intermediate effects on reduction in ERGO content in the crops. These results suggest that NT is the system that results in the highest ERGO concentrations and that increasing the intensity of tillage results in progressively less ERGO.

Another benefit of minimal tillage was the higher crop yields observed with the NT or CD systems compared to MB. Reduced crop yields with intensive tillage are not always reported [42], but were quite evident in our study. One reason may be that most trials on research stations are small and laid out on level soil, where the effects of soil erosion are small. Another reason may be that the plots used in the current study have been ongoing for more than 40 years, while most research is not that long lasting, so crop yield reductions due to soil degradation might not be noticed yet. Most non-irrigated crops in the world are grown on undulating terrain where soil degradation due to tillage is much more severe than in typical research stations. A recent study estimated that $35 \%$ of U.S. Corn Belt soils have lost the entire A-horizon due to intensive tillage [43]. These findings suggest yield reductions due to intensive tillage, such as those observed in our study, are common. Long term use of excessive tillage is a well-known cause of soil degradation and poor soil health is equated with a diminution of healthy microbial populations [44]. In this regard, a recent study compared measures of soil quality 15 years after conversion from plowing to reduced tillage [45]. In that study, soil organic carbon increased by $25 \%$, microbial biomass by $32 \%$, 
and microbial biomass activity by $34 \%$. Minimal tillage also has some important economic benefits. Reduced input costs can occur due to reduction in fuel and labor costs associated with plowing. Also, reduction in greenhouse gas emissions and runoff issues caused by erosion make it more sustainable and environmentally friendly.

Recently, there has been growing interest in implementing regenerative agriculture as an alternative to conventional agricultural methods in order to restore soil health [46]. The hallmarks of regenerative agriculture are the use of no-till or minimal tillage, the use of cover crops, and crop rotations along with reduction in the use of chemical fertilizers. The use of no-till or minimal tillage is less damaging than conventional tillage or plowing.

There is mounting interest in the connection between soil health and human health based primarily on the idea that healthy soils produce healthier foods [12]. However, there is currently a lack of a definitive link between them. ERGO may well be such a link since it is derived from the soil, and it has a growing bank of evidence for its benefits to human health. The results of this current study show the benefits of no or reduced tillage on the ERGO content of foods, which can be a model practice of studying this important link. However, there is a need to evaluate other practices employed in regenerative agriculture on ERGO content that could provide further evidence of its link to soil and human health. For example, it has been shown that brassica crops such as canola do not serve as hosts for mycorrhizal fungi and thereby reduce mycorrhiza populations in the soil for the succeeding crop [47]. Since mycorrhizae are symbiotic obligants, it is also suspected that fallow periods without living roots lead to reduced mycorrhizal colonization $[48,49]$. Further, there is some evidence pointing to reductions in mycorrhizae due to use of certain pesticides [50,51]. It is possible that these management practices could affect ERGO uptake in crops. Finally, the present results support the role of direct uptake by plants of ERGO from mycorrhizal fungi associated with their root structure. However, there is a need for further research to definitively identify the specific mechanisms of ERGO incorporation into different crops.

\section{Conclusions}

The results of this study confirmed that aggressive tillage of agricultural soils significantly reduced ERGO content in three grain crops grown over three years when compared to alternative agriculture methods involving little or no disturbance of the soil. Further, crop yields were increased with the regenerative (non-conventional) agricultural methods, indicating that it is possible to increase the ERGO content of the American food supply by using practices that can be profitable, more sustainable, and environmentally friendly. Use of minimal tillage is known to improve soil health by maintaining the abundance of microbial populations, including mycorrhizal fungi, that are thought to be the primary source of ERGO in the food supply. Since ERGO is considered to be a "longevity vitamin", its enhancement in foods may represent a critical and useful link between soil health and human health that is currently lacking. However, the mechanism responsible for the transfer of ERGO from soil microbes to the roots of plants has been underexplored and additional research is clearly needed. Also, other agricultural practices that might increase ERGO content in food crops should provide additional means to improve our long-term health outcomes.

Author Contributions: R.B.B. was responsible for the conceptualization of the work with collaboration from S.W.D. through his ongoing long-term tillage trial plots. D.S. analyzed samples for ERGO with assistance from M.D.K., S.W.D. was responsible for statistical analysis of the data. R.B.B. and M.D.K. were responsible for writing the original draft. R.B.B., M.D.K., S.W.D., J.P.R.J., D.S. and A.T.P. contributed to the review and editing of the final draft. All authors have read and agreed to the published version of the manuscript.

Funding: The cultivation of the crops used for this study was supported by the USDA National Institute of Food and Agriculture and Hatch Appropriations under Project \#PEN04764 and Accession \#1025969. The analysis of the crops for ergothioneine received no external funding.

Institutional Review Board Statement: Not applicable. 
Informed Consent Statement: Not applicable.

Data Availability Statement: Data is available upon request.

Acknowledgments: ERGO analysis was performed in the Mass Spectrometry Core Facility (small molecule) in the College of Medicine at Penn State University. We also thank Divya Pant for assistance with the statistical analysis.

Conflicts of Interest: The authors declare no conflict of interest.

\section{References}

1. Beelman, R.B.; Kalaras, M.D.; Phillips, A.T.; Richie, J.P. Is ergothioneine a "longevity vitamin" limited in the American diet? J. Nutr. Sci. 2020, 9, 1-5. [CrossRef] [PubMed]

2. Ames, B.N. Prolonging healthy aging: Longevity vitamins and proteins. Proc. Natl. Acad. Sci. USA 2018, 115, 10836-10844. [CrossRef] [PubMed]

3. Pfeiffer, C.; Bauer, T.; Surek, B.; Schömig, E.; Gründemann, D. Cyanobacteria produce high levels of ergothioneine. Food Chem. 2011, 129, 1766-1769. [CrossRef]

4. Osawa, R.; Kamide, T.; Satoh, Y.; Kawano, Y.; Ohtsu, I.; Dairi, T. Heterologous and High Production of Ergothioneine in Escherichia coli. J. Agric. Food Chem. 2018, 66, 1191-1196. [CrossRef]

5. Alamgir, K.M.; Masuda, S.; Fujitani, Y.; Fukuda, F.; Tani, A. Production of ergothioneine by Methylobacterium species. Front. Microbiol. 2015, 6, 1185. [CrossRef] [PubMed]

6. Genghof, D.S. Biosynthesis of ergothioneine and hercynine by fungi and Actinomycetales. J. Bacteriol. 1970, 103, 475-478. [CrossRef]

7. Brito, I.; Goss, M.J.; de Carvalho, M.; Chatagnier, O.; van Tuinen, D. Impact of tillage system on arbuscular mycorrhiza fungal communities in the soil under Mediterranean conditions. Soil Tillage Res. 2012, 121, 63-67. [CrossRef]

8. Dai, J.; Hu, J.; Zhu, A.; Bai, J.; Wang, J.; Lin, X. No tillage enhances arbuscular mycorrhizal fungal population, glomalin-related soil protein content, and organic carbon accumulation in soil macroaggregates. J. Soils Sediments 2015, 15, 1055-1062. [CrossRef]

9. Kabir, Z. Tillage or no-tillage: Impact on mycorrhizae. Can. J. Plant Sci. 2005, 85, 23-29. [CrossRef]

10. Frey, S.D.; Elliott, E.T.; Paustian, K. Bacterial and fungal abundance and biomass in conventional and no-tillage agroecosystems along two climatic gradients. Soil Biol. Biochem. 1999, 31, 573-585. [CrossRef]

11. Doran, J.W. Soil health and global sustainability: Translating science into practice. Agric. Ecosyst. Environ. 2002, 88, 119-127. [CrossRef]

12. Brevik, E.C.; Slaughter, L.; Singh, B.R.; Steffan, J.J.; Collier, D.; Barnhart, P.; Pereira, P. Soil and Human Health: Current Status and Future Needs. Air Soil Water Res. 2020, 13, 1178622120934441. [CrossRef]

13. Oliver, M.A.; Gregory, P.J. Soil, food security and human health: A review. Eur. J. Soil Sci. 2015, 66, 257-276. [CrossRef]

14. Abrahams, P.W. Soils: Their implications to human health. Sci. Total Environ. 2002, 291, 1-32. [CrossRef]

15. Lal, R. Soil health and carbon management. Food Energy Secur. 2016, 5, 212-222. [CrossRef]

16. Lehman, R.M.; Cambardella, C.A.; Stott, D.E.; Acosta-Martinez, V.; Manter, D.K.; Buyer, J.S.; Maul, J.E.; Smith, J.L.; Collins, H.P.; Halvorson, J.J.; et al. Understanding and Enhancing Soil Biological Health: The Solution for Reversing Soil Degradation. Sustainability 2015, 7, 988-1027. [CrossRef]

17. Gans, J. Computational Improvements Reveal Great Bacterial Diversity and High Metal Toxicity in Soil. Science. 2005, 309, 1387-1390. [CrossRef]

18. Helfrich, M.; Ludwig, B.; Thoms, C.; Gleixner, G.; Flessa, H. The role of soil fungi and bacteria in plant litter decomposition and macroaggregate formation determined using phospholipid fatty acids. Appl. Soil Ecol. 2015, 96, 261-264. [CrossRef]

19. Lehmann, A.; Zheng, W.; Rillig, M.C. Soil biota contributions to soil aggregation. Nat. Ecol. Evol. 2017, 1, 1828-1835. [CrossRef]

20. Makarov, M.I. The Role of Mycorrhiza in Transformation of Nitrogen Compounds in Soil and Nitrogen Nutrition of Plants: A Review. Eurasian Soil Sci. 2019, 52, 193-205. [CrossRef]

21. Nasim, G. Arbuscular Mycorrhizae for Sustainable Agriculture. In Crop Production for Agricultural Improvement; Ashraf, M., Öztürk, M., Ahmad, M.S.A., Aksoy, A., Eds.; Springer: Dordrecht, The Netherlands, 2012; pp. 581-618, ISBN 978-94-007-4116-4.

22. Landeweert, R.; Hoffland, E.; Finlay, R.D.; Kuyper, T.W.; van Breemen, N. Linking plants to rocks: Ectomycorrhizal fungi mobilize nutrients from minerals. Trends Ecol. Evol. 2001, 16, 248-254. [CrossRef]

23. Miller, R.M.; Jastrow, J.D. Hierarchy of root and mycorrhizal fungal interactions with soil aggregation. Soil Biol. Biochem. 1990, 22, 579-584. [CrossRef]

24. Kassam, A.; Friedrich, T.; Derpsch, R. Conservation agriculture in the 21st century: A paradigm of sustainable agriculture. Eur. Congr. Conserv. Agric. 2010, 10, 4-6.

25. Merten, G.H.; Araújo, A.G.; Biscaia, R.C.M.; Barbosa, G.M.C.; Conte, O. No-till surface runoff and soil losses in southern Brazil. Soil Tillage Res. 2015, 152, 85-93. [CrossRef]

26. Rhoton, F.; Shipitalo, M.; Lindbo, D. Runoff and soil loss from midwestern and southeastern US silt loam soils as affected by tillage practice and soil organic matter content. Soil Tillage Res. 2002, 66, 1-11. [CrossRef] 
27. Dick, W.A.; Roseberg, R.J.; McCoy, E.L.; Haghiri, F.; Edwards, W.M. Surface Hydrologic Response of Soils to No-Tillage. Soil Sci. Soc. Am. J. 1989, 53, 1520-1526. [CrossRef]

28. Dao, T.H. Tillage and Winter Wheat Residue Management Effects on Water Infiltration and Storage. Soil Sci. Soc. Am. J. 1993, 57, 1586-1595. [CrossRef]

29. Olson, K.; Ebelhar, S.A.; Lang, J.M. Long-Term Effects of Cover Crops on Crop Yields, Soil Organic Carbon Stocks and Sequestration. Open J. Soil Sci. 2014, 4, 284-292. [CrossRef]

30. Allmaras, R.R.; Schomberg, H.H.; Douglas, J.; Dao, T.H. Soil organic carbon sequestration potential of adopting conservation tillage in U.S. croplands. J. Soil Water Conserv. 2000, 55, 365-373.

31. Sheehy, J.; Regina, K.; Alakukku, L.; Six, J. Impact of no-till and reduced tillage on aggregation and aggregate-associated carbon in Northern European agroecosystems. Soil Tillage Res. 2015, 150, 107-113. [CrossRef]

32. Edwards, C.A.; Lofty, J.R. The Effect of Direct Drilling and Minimal Cultivation on Earthworm Populations. J. Appl. Ecol. 1982, 19, 723. [CrossRef]

33. Edwards, W.M.; Shipitalo, M.J.; Owens, L.B.; Norton, L.D. Effect of Lumbricus terrestris L. burrows on hydrology of continuous no-till corn fields. Geoderma 1990, 46, 73-84. [CrossRef]

34. Herridge, D.F.; Peoples, M.B.; Boddey, R.M. Global inputs of biological nitrogen fixation in agricultural systems. Plant Soil 2008, 311, 1-18. [CrossRef]

35. Sheng, M.; Lalande, R.; Hamel, C.; Ziadi, N.; Shi, Y. Growth of corn roots and associated arbuscular mycorrhizae are affected by long-term tillage and phosphorus fertilization. Agron. J. 2012, 104, 1672-1678. [CrossRef]

36. Duiker, S.W.; Beegle, D.B. Soil fertility distributions in long-term no-till, chisel/disk and moldboard plow/disk systems. Soil Tillage Res. 2006, 88, 30-41. [CrossRef]

37. Ey, J.; Schömig, E.; Taubert, D. Dietary sources and antioxidant effects of ergothioneine. J. Agric. Food Chem. 2007, 55, 6466-6474. [CrossRef]

38. Halliwell, B.; Cheah, I.K.; Tang, R.M.Y. Ergothioneine-A diet-derived antioxidant with therapeutic potential. FEBS Lett. 2018, 592, 3357-3366. [CrossRef]

39. Census of Agriculture: 2017 Census Volume 1, Chapter 1: U.S. National Level Data. Available online: https:/ /www.nass.usda. gov /Publications /AgCensus/2017/Full_Report/Volume_1,_Chapter_1_US/ (accessed on 17 March 2021).

40. Borodina, I.; Kenny, L.C.; McCarthy, C.M.; Paramasivan, K.; Pretorius, E.; Roberts, T.J.; van der Hoek, S.A.; Kell, D.B. The biology of ergothioneine, an antioxidant nutraceutical. Nutr. Res. Rev. 2020, 33, 190-217. [CrossRef] [PubMed]

41. Audley, B.G.; Tan, C.H. The uptake of ergothioneine from the soil into the latex of Hevea brasiliensis. Phytochemistry 1968, 7, 1999-2000. [CrossRef]

42. Pittelkow, C.M.; Linquist, B.A.; Lundy, M.E.; Liang, X.; van Groenigen, K.J.; Lee, J.; van Gestel, N.; Six, J.; Venterea, R.T.; van Kessel, C. When does no-till yield more? A global meta-analysis. F. Crop. Res. 2015, 183, 156-168. [CrossRef]

43. Thaler, E.A.; Larsen, I.J.; Yu, Q. The extent of soil loss across the US Corn Belt. Proc. Natl. Acad. Sci. USA 2021, 118, 1-8. [CrossRef] [PubMed]

44. Montgomery, D.R.; Bikle, A. The Hidden Half of Nature: The Microbial Roots of Life and Health; W. W. Norton \& Company: New York, NY, USA, 2016; ISBN 978-0-393-35337-2.

45. Krauss, M.; Berner, A.; Perrochet, F.; Frei, R.; Niggli, U.; Mäder, P. Enhanced soil quality with reduced tillage and solid manures in organic farming-A synthesis of 15 years. Sci. Rep. 2020, 10, 4403. [CrossRef] [PubMed]

46. Rhodes, C.J. The imperative for regenerative agriculture. Sci. Prog. 2017, 100, 80-129. [CrossRef]

47. Kabir, Z.; Koide, R.T. Effect of autumn and winter mycorrhizal cover crops on soil properties, nutrient uptake and yield of sweet corn in Pennsylvania, USA. Plant Soil 2002, 238, 205-215. [CrossRef]

48. Lekberg, Y.; Koide, R.T. Is plant performance limited by abundance of arbuscular mycorrhizal fungi? A meta-analysis of studies published between 1988 and 2003. New Phytol. 2005, 168, 189-204. [CrossRef]

49. Lehman, R.M.; Taheri, W.I.; Osborne, S.L.; Buyer, J.S.; Douds, D.D. Fall cover cropping can increase arbuscular mycorrhizae in soils supporting intensive agricultural production. Appl. Soil Ecol. 2012, 61, 300-304. [CrossRef]

50. Hage-Ahmed, K.; Rosner, K.; Steinkellner, S. Arbuscular mycorrhizal fungi and their response to pesticides. Pest Manag. Sci. 2019, 75, 583-590. [CrossRef]

51. Zaller, J.G.; Heigl, F.; Ruess, L.; Grabmaier, A. Glyphosate herbicide affects belowground interactions between earthworms and symbiotic mycorrhizal fungi in a model ecosystem. Sci. Rep. 2014, 4, 5634. [CrossRef] 